\title{
あ〉逝き給う Professor Jaroslav Heyrovsky
}

舘

1959年に Nobel 化学賞を受けられたポーラ ログラフィーの創始者, J。ヘイロフスキィー 先生が，本年(1967年) 3 月27日御逝去になった ことが全世界に報道された。御遗族やチェコス ロヴァキアの人達の御悲靯は申すまでもない が, 全世界のポーラログラフィストも驚きと深 い悲しみにつつまれた。先年(1964年 5 月 8 日) なくなられた志方益三先生はポーラログラフの 協同創案者であり，有機ポーラログラフィーの 最初の研究者であられたので, チェコとは特別 な関係にあるわが国のポーラログラフィストに とっては，その悲しみはととのほか深いもので あった。

ヘイロフスキー先生は, チェコとともにポー ラログラフィーの長い歴史をもっているわが国 のポーラログラフィストに対しては, 常に深い 信頼と敬意とを寄せておられたようであった。

先生の御業績については，乙てにあらためて 申すまでもないととであり, 御貢献の大きいて とは，世界各国から数々の栄誉を扔うけになっ ておられることであきらかである。

1966年 7 月 4 日〜 8 日の 5 日間仙わっって, 第 4 回国際ポーラログラフ会議がプラーグにお いて開かれた。 ての会議は，ヘイロフスキー先 生の75才とチェコ化学会百年記念会を祝賀して 行われたものである。私は悻にもチェコスロ ヴァキア科学学士院の扔招き仙あずかり，ての 会議に出席し、はじめてへイロフスキー先生御 夫妻注目にかかる機会が与光られた。先生は じめ研究所の方々の鄭重な歓待をおうけし, ポ ーラログラフィー発祥の地のプラーグの風物に も接するてとができた。心のこもったおもてな しや暖かい友情は私にとって終生忘れるてとの できないととである. 学会中には, 先生は奥様 につき添われられ，講演会場あるいはパーティ 一に御出席になっていた。そその先生の面影かい まも私の脳裡に浮んでくるのである。
勇

てのような鹳待をうけるととができたのる， 今はなき志方先生のお陰である。両先生は今や 還い天国で再会され，話花が咲いていること であらう。

1959年, ヘイロフスキー先生がストックフォ ルムにおいてノ一ベル賞をうけられたとき，た また同地のフォン・オイラー教授のもとに留学 中であった志方先生門下の一人野村男次博士 (山口大学農学部教授) がオイラー教授のおは からいで祝賀会にも出席された由であった。志 方先生門下の一人が祝賀会に出席したととに は，きっとへイロフスキー先生もおよろてびに なったととと思う。

ヘイロフスキー先生は実に立派なお人柄の温 厚な貴公子であられ，また，奥様はまことに先 生にふさわしい, むしろ日本的な雾囲気の，憵 㷫な淑女であられ，はじめてお目にかかつた私 ぞももほほのぼのとした暖かいものを感じま るで10年の知己という感じであった。 その上， 御曹子の M. Heyrovsky 博士もまた立派な青 年であり, 御両親に似て礼儀の正しい方であっ た。私どもはこのような先生御一家にお目にか かれたことはほんとうに深い思い出である。

私い謹んでへイロフスキー先生の御冥福をお 新り申し上げる次第である。

碩学遂に逝き給いて，私ぞもとは幽明境を異 にするが，プラーグの研究所では Vlček 教授 以下の幹部もそろっており, 分散しているへイ ロフスキー研究所も新しい一つの建物に引っ越 すとともそう遠くないと思う。一方，わが国の ポーラログラフ学会会員も多士済々であり, ポ ーラログラフィーの新天地を開拓されつつあ る. チェコとわが国はともにポーラログラフィ 一の発祥の地としての誇りをもって，斯界のた め御尽力を㹉いする次第である。

(昭和42年 5 月) 